\title{
Citizen Participation Practice in Thailand Environmental Policy
}

\author{
Prukkanone Kittisak ${ }^{1}$, Wang Guohua ${ }^{1,2}$ \\ ${ }^{1}$ College of Public Administration, Huazhong University of Science and Technology, Wuhan, China \\ ${ }^{2}$ The Public Opinion Researching Center, Huazhong University of Science and Technology, Wuhan, China
}

\section{Email address:}

kprukkanone@yahoo.com (P. Kittisak),mpawin@hust.edu.cn (Wang Guohua)

\section{To cite this article:}

Prukkanone Kittisak, Wang Guohua. Citizen Participation Practice in Thailand Environmental Policy. International Journal of Environmental Protection and Policy. Vol. 4, No. 2, 2016, pp. 24-33. doi: 10.11648/j.ijepp.20160402.11

\begin{abstract}
Environmental Policy is a major mechanism for the government to drive the public administration on environmental management. In Thailand, some citizens were significantly affected from the inadequacy of Public Participation in Environmental Policy and leaded to widespread conflicts about their interests in society. Although the Constitution of the Kingdom of Thailand B. E. 2550 (2007) attempted to broadly open the opportunities on Public Participation in the environmental management but the interest conflicts were still existed. This article studied on Thailand Environmental Policy, especially examined the Citizen Participation Practice in the Environmental Policy Formulation which would contributed the further development in public administration aspect. The current national environmental policy, the Environmental Quality Management Plan B. E. 2555-2559 (2012-2016), was selected as the case study and analyzed to examine Citizen Participation Practice under the policymaking context by the principle of citizen participation "Perceptions of Stakeholders and Planners: the ladder of citizen participation" and the concept of environmental policymaking in government. Related documents and researches, environmental laws and regulations, and policies were reviewed, analyzed and synthesized for appropriately conducting in the study. The results were found that Thailand had an appropriate framework on citizen participation in the Environmental Policymaking Process regarding the provisions of constitution but it was limited by the provisions of older laws and policies which were enacted before the 2007 Constitution was promulgated. All of Citizen Participation Practices were located in the category of Tokenism, where the citizens became involved but only to certain extent. This is not meaningful in term of citizen control which should be appropriately conducted in the democracy society. Thailand did not have Citizen Participation Practices in the category of Nonparticipation and the current national environmental policy open an opportunity for amendment on Environmental Legislation. These findings were benefit to the better development of Citizen Participation Practice in Thailand Environmental Policy, which would be opened the participatory opportunity on the interest conflict resolution in the future.
\end{abstract}

Keywords: Thailand Environmental Policy, Citizen Participation Practice, Policymaking Process, Public Participation

\section{Introduction}

Since 1932, Thailand has changed the country regime from an absolute monarchy to a constitutional monarchy by adopting a democratic regime of government with the King as Head of the State and the sovereign power belongs to the Thai Citizen [1]. Nevertheless, so far, Thai citizen still faced the problems and conflicts on their participation, especially in the environmental issues which the number of conflicts between the public and the government has obviously increased during the past few years.

This problem reflected in the statistic of the proceeding cases about public administration concerning environmental issues through Administrative Court of Thailand during 2011-2015 that citizen sued the Public Agency which found that there were 5,131 proceeded cases. In addition, regarding the Top Ten Ministries Ranking of Defendant in Administrative Court of Thailand 2011-2014, Ministry of Natural Resources and Environment (MNRE) was ranked seventh of the Defendant of Public Agency in the ministry level [2] as shown in Table 1.

Throughout Thailand's environmental management history, Thailand Political and Legal System authorized the government to manage natural resources and environment with 
absolute power, it was top-down management and obviously ineffective. Particularly, decisions about environmental protection and management often failed to integrate the opinions of citizen. Citizen Participation Practice was often avoided and limited. The decision-makers preferred to keep control over the decision and refused to share their authority. The citizen had few opportunities to influence the decisions. It was an important obstacle to achieve effective process and this could lead to more environmental problems and interest conflicts in Thai Social. Some citizens lost trust and developed an unfavorable attitude towards governmentsponsored participation and refused to engage in the government-sponsored participatory activities [3].

Table 1. Top Ten Ministries Ranking of the Defendant of Public Agency in Administrative Court of Thailand, 2011-2014.

\begin{tabular}{lll}
\hline Ranking & The Defendant of Public agency (Ministry level) & Cases \\
\hline 1 & Ministry of Interior & 19,943 \\
2 & Ministry of Transport & 12,490 \\
3 & Ministry of Agriculture and Cooperatives & 10,676 \\
4 & Ministry of Education & 8,198 \\
5 & Office of the Prime Minister & 6,354 \\
6 & Ministry of Finance & 5,535 \\
7 & Ministry of Natural Resources and Environment & 3,183 \\
8 & Ministry of Public Health & 1,477 \\
9 & Ministry of Justice & 1,250 \\
10 & Ministry of Energy & 1,101 \\
& Total & 70,207 \\
\hline
\end{tabular}

The environmental and interest conflicts were acknowledged by Thai Social and there was an attempted to use the appropriate citizen participation for solving the problem through the constitution which acts as the mother law of the country. Thailand's constitution were promulgated and amended through 18 constitutions in accordance with the evolving situation of country. In particular, Constitution of the Kingdom of Thailand B. E. 2540 (1997), the $17^{\text {th }}$ constitution is an initiative of Participatory Democracy in Thailand's history. The 1997 Constitution is considered as the fundamental to Thai modern political reform and recognized a wide range of basic rights, particularly in the voicing of public opinion on issues of national importance and safeguarding people's dignity [4]. This Constitution was promulgated and mandated important provisions in political reform, establishment of independent organizations, administrative decentralization, public participation in natural resources and environmental management as well as the guarantee of the community rights for the first time [5].

Although Thailand's constitution was transformed to the $18^{\text {th }}$ Constitution, the Constitution of the Kingdom of Thailand B. E. 2550 (2007), still concerned on public participation in natural resources and environmental management aspect and had been modified to enhance this role, which citizen was explicitly endorsed and safeguarded the right to participate as enshrined in several sections of, the law ensuring the right to have a good environment and ensuring people participation with respect to health, laws concerning access to public documents, concerning public participation, and those concerning access to environmental justice.
The 2007 Constitution was used as a legal framework for formulating the current environmental policy of Thailand which looked seem good in principle where government formulate the environmental policy by providing the participation activities according to the constitution, but in practice, some citizen perceived that participation was merely a ritual aimed at legitimizing government decision-making and was done merely to ensure that decisions did not violate any legal provisions. As this was not meaningful participation, the country wasted substantial funds in organizing participation activities which did not have any effect on governmental policies or projects [3].

This article examined Citizen Participation Practices in Thailand's Environmental Policy Formulation Process, which the Environmental Quality Management Plan B. E. 2555-2559 (2012-2016) was considered as a case study. Therefore, the 2007 Constitution, Environmental Laws and Regulations related to Citizen Participation Practice in Thailand, including with Citizen Participation Principle and Environmental Policy Theory were reviewed, analyzed and applied for conducting in the study.

\section{Literature Review}

\subsection{Citizen Participation and Environmental Policy Formulation}

First and foremost, it is important to understand the relationship between Citizen Participation and Environmental Policy Formulation in term of the equilibrium of public management under the paradigm that humans can survive their quality of life with balancing between environmental and social capital. However, due to the social capital, the public management regarding the environmental service circumstance in actual world was fallen down to the awkward situation because the majority of natural resources and environment was being depleted both quality and quantity aspect, meanwhile the human needs were dramatically increasing. These are predicted that can severely affect both the human and environmental quality in the near future.

Generally, Attributions of the environment can be thought of as environmental capital capable of providing services which people can use [6]. People use the environment to support their demand in several aspects which are knew as an environmental service: a service that environment provides for the individuals who comprise the human race, which the valuables are depended on their characteristics that can fulfill the resources needed to the human such as; procure shelter, safety, aesthetic pleasure, spiritual sustenance and so on.

Conceptualizing the environment in terms of its ability to service the human race is an approach increasingly used by environmental policy makers. This approach is a prominent point that challenges the environmental policy makers or government takes into account the policy output that achieved the sustainable utilization concept under a thin 
dividing line between 'the human needs' and 'the environmental capital capable'.

In the democratic country, the environmental policy makers or government is often emphasizing democratic decision-making principles in the policy-making process to ensure that all that are affected by a given decision have the right to participate in the making of that decision. The participation is seen as an instrument for ringing public values, social objectives and preferences to decision processes that are primarily analytical [7].

Citizen participation is a process which provides private individuals an opportunity to influence public decisions and has long been a component of the democratic decisionmaking process. The roots of citizen participation can be traced to ancient Greece and Colonial New England. Before the 1960s, governmental processes and procedures were designed to facilitate "external" participation. Citizen participation was institutionalized in the mid-1960s with President Lyndon Johnson's Great Society programs [8].

Cogan and Sharpe [8] identify five benefits of citizen participation to the planning process: 1) Information and ideas on public issues; 2) Public Support for planning decisions; 3) Avoidance of protracted conflicts and costly delays; 4) Reservoir of good will which can carry over to future decisions; and 5) Spirit of cooperation and trust between the agency and the public.

\subsection{The Principle of Citizen Participation, Perceptions of Stakeholders and Planners}

This article, adopted the principle of citizen participation, Perceptions of Stakeholders and Planners, to examine Citizen Participation Practice in Thailand's environmental policy formulation process, which are described as following.

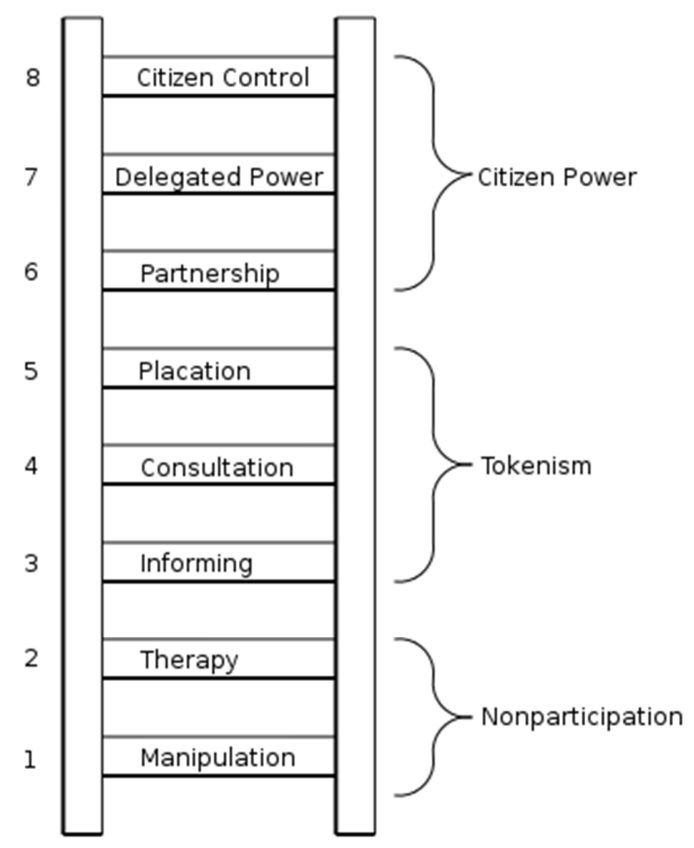

Source: Sherry R. Arnstein [9]

Figure 1. The Ladder of Citizen Participation.
The Perception of Stakeholders and Planners is an important consideration in the development and implementation of any public participation program. In the successful citizen involvement programs or policies, the disparity between the policy makers or government and the citizen's expectations must be stated in minimal. If expectations are different, conflict is probable [8].

To assist the policy makers in determining the perceptions of a policy's purpose and compare this with the anticipated perceptions of citizen participants, the "ladder of citizen participation" of Sherry R. Arnstein [9] is one of the best practices that can provide an overview of the different ways the public can be involved in decision-making. It describes eight levels of participation, which are divided into three main categories. These levels can be represented as a ladder, as shown in Figure 1.

\subsubsection{Nonparticipation $\left(1^{\text {st }}-2^{\text {nd }}\right.$ Level)}

This is where the public is not directly involved and may be manipulated into thinking they are part of decisionmaking, where the power holders have created a phony form of participation, perhaps around a decision already made.

$1^{\text {st }}$ level: Manipulation, which is where people are "educated" and may be advised to sign proposals they believe to be in their interest.

$2^{\text {nd }}$ level: Therapy, involves the power holders "curing" the people. The power holders promise to assist the citizens and have them engage in different activities where their opinions may be "cured", and in the end accepted by the citizens.

\subsubsection{Tokenism $\left(3^{\text {rd }}-5^{\text {th }}\right.$ Level)}

This is where the citizens become involved but only to certain extent.

$3^{\text {rd }}$ level: Informing, this is where the citizens are informed of what is happening. This is a one-way information process, where people receive the information in newspapers, in the media, online or by other means.

$4^{\text {th }}$ level: Consultation, in which citizens' opinions can start to affect the power holder's opinion. This is a common form of citizen participation utilized in urban planning. If consultation and information is taken into account as part of the planning process, this can be effective. However, if the consultation and information is not taken into consideration at the end of the day, this step will be of limited value and could therefore fall back into the non-participating level.

$5^{\text {th }}$ level: Placation, the level is where a citizens' opinion will start influencing the power holder's decision. At this level, citizens may be hand-picked to sit on a governing board that makes decisions on the planning process. This process is more likely to work if the board members are equally split (citizens and power holders), so the citizens cannot be outvoted in the process.

\subsubsection{Citizen Power $\left(6^{\text {th }}-8^{\text {th }}\right.$ Level)}

This is where the citizens get to influence the decisionmaking directly.

$6^{\text {th }}$ level: Partnership, the power holders and citizens 
create a partnership. Arnstein considers partnership relatively high on her ladder as she believes this can keep both citizens and power holders content.

$7^{\text {th }}$ level: Delegated Power, the citizens can start taking control, and the power holders need to start negotiating with the citizens. Compared to the example given for placation (the fifth level), the majority of the board members would be the citizens. This would mean that the power holders would need to negotiate decisions with the board members. This process is more likely to work if the board members are equally split (citizens and power holders), so the citizens cannot be outvoted in the process.

$8^{\text {th }}$ level: Citizen Control, it gives the citizens the power to decide. This can be achieved through referendums, but since those are often costly and difficult to arrange it would most likely slow down the process substantially. They are therefore often only utilized for larger decisions. In many cases, local authorities do not, however, give their citizens full control in such elections, but treat the results instead only as advisory for the final decision made by the city council or other such decision making bodies, citizens may be hand-picked to sit on a governing board that makes decisions on the planning process.

\section{Methodology}

This article is conducted by the case study research by selecting the current national environmental policy, Environmental Quality Management Plan B. E. 2555-2559 (2012-2016) as the case study. For the basic proposition of the case study was the application of Citizen Participation Practice under the provisions of 2007 Constitution to contribute the further development in the public administration on environmental management.

The secondary data of related documents and researches, government reports, environmental laws and regulations, and policies were reviewed, analyzed, and synthesized with the primary data from the stakeholder interviews for appropriately conducting in the study. The Policymaking Context of the Environmental Quality Management Plan 2012-2016 was simulated under the concept of environmental policymaking in government and the principle of citizen participation 'Perceptions of Stakeholders and Planners: the ladder of citizen participation' was applied to describing Citizen Participation Practice in Thailand's environmental policy formulation process.

The analytic strategy for analyzing case study evidence was the relying on theoretical proposition, which the theoretical orientation in this study examined Citizen Participation Practice in Thailand's Environmental Policymaking Process and described that how the formation and modification in the policy formulation process occurred, and how the relevant actors acted to contribute the provisions of 2007 Constitution.

\section{Result and Discussions}

\subsection{Environmental Policy in Thailand - Steps, Policies and Laws Framework}

The Government of Thailand had initiated the following steps to develop the environmental policy formulation in Thailand.

\subsubsection{Historical Period}

Before 1972, Thailand did not has the governmental organization responsible for handling environmental management in the country, therefore the common environmental policy in majority is conducted through the related acts concerning the preservation of natural resources was enacted. The examples of these acts are Forest Act 1941, Fisheries Act 1947, National Park Act 1961, Field Dyke and Ditches Act 1962, National Reserved Forest Act 1964, Petroleum Act 1971.

\subsubsection{Initiating Period}

In 1972, After Thailand participated in the Stockholm conference on the human environment, the government recognized the need for environmental management then established the office of National Environment Board (ONEB) to serve as the secretariat office in the central authority for coordinating environmental management of the country.

\subsubsection{The Improvement and Conservation of National Environmental Quality Act 1975 (NEQ Act 1975)}

This was the first and specific environmental law of Thailand which was proved inefficient as it was enacted to support the operation of the National Environment Board (NEB), an advisory body for the Prime Minister on environmental policy. Not only being empowered to carry out any implementation on its own, the National Environment Board was required to seek co-operation from other governmental agencies which was seldom successful.

\subsubsection{The Enhancement and Conservation of National Environmental Quality Act 1992 (NEQ Act 1992)}

After the 1991 coup d'état, Thailand was repeals and amendments of various laws concerning country development. The NEQ Act 1975 was also repealed and re-enacted as the NEQ Act 1992 with its objectives of being a basic comprehensive environmental law incorporating various aspects of environmental management.

\subsubsection{The Enhancement and Conservation of National Environmental Quality Policy and Plan 1997-2016 (NEQ Plan 1997-2016)}

Office of Natural Resources and Environmental Policy and Planning (ONEP) under the Ministry of Natural Resources and Environment was mandated as a governmental agency, acting the secretariat office of the National Environment Board, responsible for this policy-making process [10]. This policy was a long-term plan that legitimated to be the twenty years master plan for implementation of the national 
policy and plan for enhancement and conservation of environmental quality. This plan was started to conduct the policy-making process in 1996 and proclaimed in 1997 respectively.

\subsubsection{The Environmental Quality Management Plan 2012-2016 (EQM Plan 2012-2016)}

This is the current environmental policy of Thailand. This policy is the intermediated plan that legitimate under the NEQP 1997-2016. It was designed to be the 5 years plan for implementation of the national policy and plan for enhancement and conservation of environmental quality. Before this plan there are two plans which was conducted and proclaimed in B. E. 2542 (1999), and 2550 (2007) respectively.

For the purpose of this article, the most relevant piece of legislation that affected to the current environmental policy formulation was the 2007 Constitution. It introduced several new provisions on the issue of environmental management, promoted and supported public participation in environmental management and conservation more than any previous constitution. The five fundamental principles regarding environmental management and public participation were determined as follows:

i. The right of the public and local community to conserve and use their environment and resources sustainability

ii. The right to control and minimize the pollution that impacts their quality of life

iii. The right of the individual and community to reduce the government's sole decision-making power over natural resource management

iv. Provision of a guarantee of access to information by the public

v. Public participation

The study applied the concept of environmental policymaking in government to conceptualize the environmental policy formulation as a cycle [6], the five main components (policy environment, inputs, government, outputs, and outcomes). This concept was applied to simulate the Policymaking Context of EQM Plan 2012-2016 as shown in Figure 2.

For the purpose of this article, the context has been analyzed only the policy-formulation process by focusing on the four main components (except outcomes) those are; policy environment, inputs, government, and outputs. The rational-relationship regarding the policy-formulation process both the policy actors and their roles, and the interactions of Citizen Participation Practice under the policy context were discussed as following.

\subsection{Citizen Participation Practice in Thailand Environmental Policy - An Analysis}

\subsubsection{Policy Environment}

In this component, there were five actors that were categorized their roles into two aspects those shaped the policy environment which are consist;

$i$. The political complexion of the government aspect and prevailing public political ideologies in environmental issue

The first actor, the 2007 Constitution played a major role on behalf of the supreme law of Thailand which prevailed over other laws passed by parliament. The NEQ Act 1992 was the second actor which acted as the principle of environmental law in Thailand. The third actor had the important role in this context were, Bilateral and Multilateral Environmental Agreements (MEAs) which bonded the international agreements created between two or multiple nations that pledged to conduct their operations in such a way that limited negative environmental impacts. This was operated in accordance with the principle of environmental management in the globalization era which the environmental issue became to the global issue.

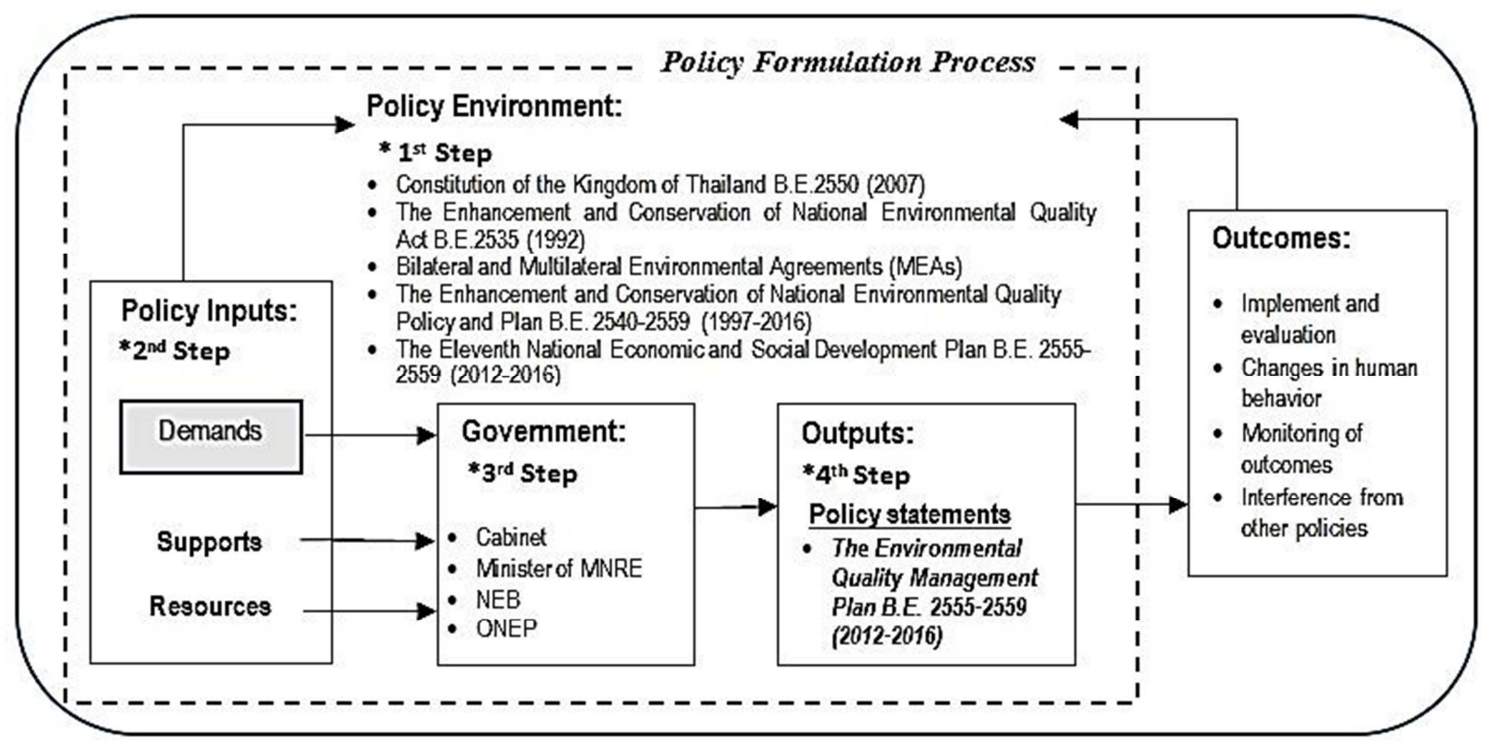

Note: * step of the policy formulation process adapted from Roberts [6]

Figure 2. The Policymaking Context of the Environmental Quality Management Plan 2012-2016. 
ii. The fundamental information about the economic and social circumstances, and the state of natural resources and environment

The fourth and fifth actor was consisting of The NEQ Plan 1997-2017 and the Eleventh National Economic and Social Development Plan B. E. 2555-2559 (11 $1^{\text {th }}$ NESD Plan 2012-2016). They presented and interpreted the fundamental information about the economic and social circumstances [11], and the state of natural resources and environment of Thailand into public sphere through the policy framework which ONEP (the responsible agency) had to mediate these information into the environmental policy-formulation process.

\subsubsection{Policy Input}

Underneath this component, the three sub-components: Demands, Supports, and Resources were operated in the policy system. They configured the policy inputs on the different basis which could be described in each as follows.

$i$. Demands: 'the perceived problems affecting various interests will lead to pressure for policies to be formulated to address the problem' was a common role for the actors in this sub-component [5]. There were five actors playing this role which consist of 1) Thailand public opinion in environmental management, 2) Evaluated result of Thailand's Environmental Quality Management Plan 2007-2011, 3) The five year forecast on Political Economic Socio-cultural Technological Components, 4) The five year forecast on the environmental management scenario, and 5) The five year forecast on the environmental legislation and amendment.

ii. Supports: 'Public advocated and obeyed with the policy context' was the essential factor for conducting this process. In this study, there were two main actors; including 1) Citizen and 2) Government agencies, they played a major role through the comprehensive public hearings which co-operated between them and the policymaker agency as ONEP.

iii. Resources: This sub-component had role that emphasized on 'The important things that required implementing the policy'. There were three actors in this role including 1) ONEP, 2) Donors, and 3) Government agencies.

\subsubsection{Government}

The decision-making process within government was played by the four relevant actors which consist of 1) ONEP, 2) National Environment Board, 3) Minister of Natural Resources and Environment, and 4) The cabinet. Their decision-making process depends on the authorization power from the NEQ Act 1992 given to government [12]. Another thing that the government must take into consideration in the decision-making process was the relevant national policy frameworks which include the NEQ Plan 1997-2017 and the $11^{\text {th }}$ NESD Plan 2012-2016.

\subsubsection{Outputs}

The major role of this component was 'The implementations or actions that could change or affect the people's behavior to follow the policy context'. The major variables which contributed to the successful implementation of policy was taken into account, and found that there were two actors those directly related to the successful in this policy, including 1) Citizen and 2) Government agencies. Particularly, the governmental agencies, the law-binding agencies under Sec. 35 of the NEQ Act 1992 to take actions within their powers and functions those were necessary for effective implementation of the EQM Plan 2012-2016.

\subsubsection{Citizen Participation Practice Under the Policy Context}

It was considered as the context of Citizen Participation Practice in each step of the policy formulation process. The participation opportunities were analyzed and examined their context as following.

i. $1^{\text {st }}$ Step: It was focused on the framework on participation that opened the opportunities for citizen to participate in the environmental policy-formulation process. The 2007 Constitution was claimed to the scope of framework which was discussed as follows.

The 2007 Constitution had provisions affirming right and freedoms of citizen in the subject of participation on management of natural resources and environment which was covering three dimensions:

a. The right of access data and information: There were three relevant sections in the 2007 constitution which contributed to this study (Section 45, 56, and 57). All of Citizen Participation Practices were interpreted in term of individual level as illustrated in Figure 3.

b. The right of participation by the citizen: The five relevant sections were contributed to this study (Section 58, 66, 67, 287 and 290) and Citizen Participation Practices were interpreted in two forms both the individual and the community level as illustrated in Figure 4.

c. The right of access to the justice system: The four relevant sections represented the citizen participation which contributed to this study (Section 28, 40, 60, and 67 (Para. 3)). Citizen Participation Practices were interpreted in two forms both the individual and the community level as illustrated in Figure 5.

ii. 2nd Step: It was focused on the process of policy input under the policy context and found that the opportunities to participate in this process was widely opened to public, the proportion of citizen that contributed in term of actors was two-third from three sub-components (except the resources).

Due to the aforementioned reason, Thailand public opinion in environmental management (from the demands) and the comprehensive public hearings (from the supports) were considered as the Citizen Participation Practice in this process. 
Section 45 , A person shall enjoy the liberty to express his or her opinion, make speeches, write, print, publicise and $m$ ake expression by other $m$ eans...... The censorship by a competent official of news or articles before their publication in a newspaper or other mass $m$ edia shall not be m a de ........

Section.56, A person shall have the right to know and have access to public data or information in possession of a Govemm ent agency......., unless the disclosure of such data or information shall affect the security of the State, public safety or interests of other persons which shall be protected or purport to be personal data, as provided by law.

Section 5 h $\mathrm{A}$ person shall have the right to receive data, explanations and reasons from a Governm ent agency...... and shall have the right to express his or her opinions to agencies concemed, for assisting further consideration of such matters.

In planning social, economic, political and cultural developm ent, or in undertakingex propriation, town and country planning zoning and $m$ aking by laws likely to have im pacts on essential interests of the public, the State shall cause to be held comprehensive public hearings prior thereto.

Figure 3. The three relevant sections on the right of access data and information.

Section 58. A person shall have the right to participate in the decision-making process of State officials in the perform ance of a dm inistrative functions which affect or $m$ ay affect his or her rights and liberties.

Section 66. Persons so a ssem bling as to be a com m unity, a local com m unity or a tra ditional com m unity shall have the right to ..... participate in the managem ent, maintenance, preservation and exploitation of natural resources, the environm ent ...

Section 67 ......Any project or activity which may seriously affect the community with respect to the quality of the environm ent, natural resources and health shall not be permitted, unless, prior to the operation thereof, its impacts on the quality of the environm ent and on public health have been studied and assessed and a public hearing process has been conducted ........

Section 287. Local residents have the right to participate in the administration of a local govemment organization. For this purpose, a local govemm ent organization shall also $m$ ake available $m$ eans for such public participation.

Section 290. A local govemm ent organization has powers and duties in connection with the prom otion and $m$ aintenance of the quality of the environm ent as provided by law .....

Figure 4. The five relevant sections on the right of participation by the citizen.

Section 28. A person can invoke hum an dignity or ex ercise his or her rights and liberties in so far as it is not in violation of rights and liberties of other persons or contrary to the Constitution or good morals.......

A person $m$ ay have a recourse to the Court for directly enforcing the State to comply with provisions in this Chapter. Where the ex ercise of any particular right or liberty as recognized by this Constitution is a subject$m$ atter of the existinglaw, such right and liberty shall be ex ercisable as provided by law.....

Section 40 , A person shall have the following rights in the a dministration of justice:

(1) the right to have easy, expeditious, speedy and com prehensive access to justice;

(2), (3), (4), (5), (6), (7) .......

Section 60, A person shall have the right to file a lawsuit against a Governm ent agency, a State agency, a State enterprise, a local governm ent organization or other State authority which is a juristic person to be liable for an act or omission done by its Govemm ent official, of ficial or em ployee

Section 67.(Paxa 3). The right of a community to bring a lawsuit against a Governm ent agency, a State agency, a State enterprise, a local governm ent organization or other State authority which is a juristic person for the perform ance of duties under this provision shall be protected.

Figure 5. The four relevant sections on the right of access to the justice system.

iii. $\quad 3^{\text {rd }}$ Step: The decision-making process of government was focused under the policy context and found that the NEQ Act 1992 was played a major role regarding the opportunities of citizen to participate in this process. There were some part of the NEQ Plan 1997-2017 and the 11th NESD Plan 2012-2016 that promoted the Citizen Participation Practice which could be discussed as follow. 
Those relevant law and policies had provisions affirming participation of citizen in the subject of environmental policy making which was covering two dimensions:

a. The public participation in the enhancement and conservation of national environmental quality: This covered the three relevant provisions in the NEQ Act 1992, the NEQ Plan 1997-2016, and the $11^{\text {th }}$ NESD Plan 2012-2016. Citizen Participation Practices were interpreted in two forms both the individual and the community level as illustrated in Figure 6.

b. The decision-making process in the environmental policy formulation: This covered the five relevant sections under the NEQ Act 1992 which all of Citizen Participation Practices were interpreted in term of the citizen's representative as illustrated in Figure 7.

The Enhancement and Conservation of National Environmental Quality Act B.E.2535 (1992)

Section .6. For the purpose of public participation in the enhancement and conservation of national environm ental quality, the following rights and duties $m$ ay be accorded to individual person as provided by this Act or goveming law related thereto:

(1) To be inform ed and obtain inform ation and data from the governm ent service .......

(2) To be rem edied or compensated by the State

(3) To petition or lodge complaint against the offender in case of being a witness .....

(4) To co-operate and a ssist govemm ent officials in the perform ance of duty ........

(5) To strictly observe the provisions of this Act or other laws conceming ............

The Enhancement and Conservation of National Environmental Quality Policy and Plan B.E. 2540-2559 (1997-2016)

The Enhancem ent and Conservation of Nationa1 Environm enta1 Quality Policy (including6 Policies)

Policy no 5. The Education and Public Relation for Enrironment

Strengthen the capability of communities in any level, to be strength and able to initiate the co-operation movem ent for the efficient in natural resource and environm ental $m$ anagem ent.

The Eleventh National Economic and Social Development Plan B.E. 2555-2559 (2012-2016)

Strategy of ManagingNatural Resources and the Environment to Achieve Sustainability

Strategy 5.8 Enhance natural resource and environm ental $m$ anagem ent system $s$ so they are more efficient, transparent and equitable, following these guideline:

5.S.1 Empower communities and support local rights to utilize natural resources in a balanced and sustainable manner.

5.S.2 Support popular participation and develop com m unity abilities....... .

Figure 6. The three relevant provisions on the public participation in the enhancement and conservation of national environmental quality.

The Enhancement and Conservation of National Environmental Quality Act B.E.2535 (1992)

Section. In order to encourage public participation in the prom otion and conservation of environm ental quality, non-governm ental organizations (NG0s) having the status of a juristic person .....

Section. 8 . The registered NG0s may propose for nom ination of candidates as representatives of the private sector to be appointed by the cabinet as qualified $m$ em bers of the National Environm ent Board.

Section 12. There shall be a National Environm ent B oard consisting of the Prim e Minister as the Chairm an, a Deputy Prime Minister designated by the Prime Minister as the first Vice Chairman, the Minister of Natural Resources and Environm ent as the second Vice Chairm an, the Minister of Defense, the Minister of Finance, the Minister of Agriculture and Cooperatives, the Minister of Transport, the Minister of Information and Comm unications, Technology, the Minister of Interior, the Minister of Education, the Minister of Public Health, the Minister of Industry, the Secretary-General of the National Economic and Social Developm ent Board,the Secretary-General of the B oard of Investm ent, the Director of the Bureau of the Budget as $m$ em bers ex officio and ** members qualified in environmental matters not more than eight persons of which no less than half shall be representatives from the private sector and the Perm anent Secretary of the Ministry of Natural Resources and Environm ent as $m$ em ber and secretary.

** The appointment of qualified members shall be made bv drawing from persons who are knowledgeable and known for their expertise. contributions and experiences in the matters concerning the enhancement and conservation of environmental gualitv.

Section 13. The National Environm ent Board shall have the power and duty as follows

(1) To submit policy and plan for enhancem ent and conservation of national environm ental quality to the cabinet for approval.

Section 35. The Minister shall, with the approval of the National Environm ent Board, formulate an action plan called 'Environm ental Quality Managem ent Plan" for im plem entation of the national policy and plan for enhancem ent and conservation of environm ental quality determ ined by virtue of section 13 (1).

Figure 7. The five relevant provisions on the decision-making process in the environmental policy formulation. 
iv. $\quad 4^{\text {th }}$ Step: It focused on the policy statements of the EQM Plan 2012-2016 (case study) and found that the opportunities of citizen to participate in this process in not quite widespread. Majority of citizen participation practices were binding the government agencies. And, there were some parts of this plan that promoted the citizen participation practice which could be discussed as follows.

The policy statements were covered six strategies and Citizen Participation Practice was emphasized in the third strategy, the natural resource and environmental management for strengthening the good governance. The overview of this strategy was stated the practice merely the public hearing and the permission to access the public information.

Summary of Citizen Participation Practices from the analyzing on the $1^{\text {st }}-4^{\text {th }}$ Step were integrated and compared with the ladder of citizen participation, to determine the perceptions of a policy's purpose and compare this with the anticipated perceptions of citizen participants as shown in Table 2 below.

Table 2. Citizen Participation Practices in Thailand Environmental Policy.

\begin{tabular}{|c|c|c|c|c|c|c|}
\hline \multicolumn{2}{|l|}{ Arnstein's } & \multirow{2}{*}{$\begin{array}{l}1^{\text {st }} \text { Step } \\
\text { Participation } \\
\text { Framework }\end{array}$} & \multirow{2}{*}{$\begin{array}{l}2^{\text {nd }} \text { Step } \\
\text { Policy Input } \\
\text { Process }\end{array}$} & \multirow{2}{*}{$\begin{array}{l}3^{\text {rd }} \text { Step } \\
\text { Decision-making } \\
\text { Process }\end{array}$} & \multirow{2}{*}{$\begin{array}{l}4^{\text {th }} \text { Step } \\
\text { Implementation } \\
\text { Process }\end{array}$} & \multirow[b]{2}{*}{ Remark } \\
\hline Ladder of citizen & ipation & & & & & \\
\hline \multirow[t]{2}{*}{ Citizen power } & $\begin{array}{l}\text { Citizen Control } \\
\text { Delegated Power }\end{array}$ & Yes & - & - & - & $\begin{array}{l}\text { The } 2007 \text { Constitution } \\
\text { - Sec. 28, 40, 58, 60, and } 67 \text { (Para. 3) } \\
\text { The } 2007 \text { Constitution } \\
\text { - Sec. } 287,290\end{array}$ \\
\hline & Partnership & Yes & - & - & - & $\begin{array}{l}\text { The } 2007 \text { Constitution } \\
\text { - Sec. } 66,67\end{array}$ \\
\hline \multirow{3}{*}{$* *$ Tokenism $* *$} & Placation & Yes & - & Yes & Yes & $\begin{array}{l}\text { The } 2007 \text { Constitution } \\
\text { - Sec. } 66,67 \\
\text { The NEQ Act } 1992 \\
\text { - Sec. } 7,8,12,13,35 \\
\text { The NEQ Plan 1997-2017 } \\
\text { - Policy no. } 5 \\
\text { The } 11^{\text {th }} \text { NESD Plan } \\
\text { - Strategy } 5.8 \\
\text { The Policy Statements } \\
\text { - Strategy } 3\end{array}$ \\
\hline & Consultation & Yes & Yes & - & Yes & $\begin{array}{l}\text { The } 2007 \text { Constitution } \\
\text { - Sec. } 45,56,67 \\
\text { The Policy input } \\
\text { - Public Opinion, Public Hearing } \\
\text { The Policy Statements } \\
\text { - Strategy } 3\end{array}$ \\
\hline & Informing & Yes & Yes & - & Yes & $\begin{array}{l}\text { The } 2007 \text { Constitution } \\
\text { - Sec. } 45,56,67 \\
\text { The Policy input } \\
\text { - Public Opinion, Public Hearing } \\
\text { The Policy Statements } \\
\text { - Strategy } 3\end{array}$ \\
\hline Nonparticipation & Therapy & - & - & - & - & - \\
\hline
\end{tabular}

\section{Conclusions}

The study was examined Citizen Participation Practices in Thailand Environmental Policy under the case study, the Environmental Quality Management Plan 2012-2016. This could be seen that Thailand had an appropriate framework on citizen participation in the environmental policy formulation process regarding the provisions of 2007 Constitution which should have successfully implement the environmental policy in accordance with the anticipated perceptions of citizen. Unfortunately, the provisions of 2007 Constitution could not efficiently transform to the environmental policy formulation in each process.
All of Citizen Participation Practices were located in the category of Tokenism, where the citizens became involved but only to certain extent. Particularly, in the most important process such a decision-making process, citizens did not have the appropriate role to govern themselves which the majority of authority was given to the government through the officials and the politicians, even the NEQ Act 1992 was opened the opportunity to the selected citizens from private sector to join in the National Environment Board (NEB) but it was very few amount when compared to the proportion with the other board members (8: 16 persons), this was not meaningful in term of citizen control which should be appropriately conducted in the democracy country such Thailand.

Furthermore, due to the public administration on 
environmental management in the international circumstance, the study did not found any linkage between Citizen Participation Practice and Bilateral and Multilateral Environmental Agreements (MEAs) under the policymaking context. This weak point would affected to the environmental service circumstance of citizen and inevitably leads more interest conflicts to Thai society when Thailand's government necessary to bonded with the international environmental agreements in the future.

Nevertheless, in the optimistic view, this study was shown that Thailand did not have the Citizen Participation Practices in the category of Nonparticipation and the environmental policy formulation was opened opportunity to amend and develop through the process of the environmental legislation under the implementation of EQM Plan 2012-2016 (case study). Therefore, it was necessary to properly implement the policy in this aspect to converge the purpose of citizen participation for relieving the conflicts and developing the sustainable co-operation movement in the future of Thailand's natural resource and environmental management.

\section{References}

[1] The Constitution of the Kingdom of Thailand B. E. 2550 (in Thai), August 24, 2007, Royal Gazette, Thailand. Vol. 124.

[2] ThaiPublica News (Online), 2015, Statistic of the administrative cases concerning environmental issues that citizens sue the Public Agency through the Administrative Court of Thailand between 2011-2015 (in Thai). Retrieved on October, 10, 2015 from http://thaipublica.org/2015/03/14thanniversary-admincourt/.

[3] Thailand Environment Institute (TEI); King Prajadhipok's Institute (KPI); Sustainable Development Foundation (SDF), 2007, The Access Initiative (TAI) Assessment in Thailand: Synthesis report on "Good Environmental Governance: Public Participation Indicators for Thailand's Sustainable Development (Third Assessment) (Synthesis report under the Project Policy Strategy on Tropical Resource Base under the National Human Rights Commission of Thailand): Thailand Environment Institute (TEI).
[4] The Government Public Relations Department, 2013, Thailand's Constitutions Moving from Representative Democracy to Participatory Democracy. Retrieved on October 10, 2013 from http://thailand.prd.go.th/ebook/review/content. php ?chapterID $=61$.

[5] Sutthiprasid, Ganniga, 2011, Evolution of Thai Environmental Law, Administrative Court of Thailand: Trimester Newsletter. Vol. 2, April - June 2011. Retrieved November, 30, 2014 from http://www.admincourt.go.th/00_web/environment/newsletter 02.htm.

[6] Jane, Roberts, 2004, Environmental Policy, London: Routledge (an imprint of the Taylor \& Francis Group).

[7] Chaisomphob, TAWEEP; Sa-nguanmanasak, JATURONG; and Swangjang, KANOKPORN, 2004, Role of Public Participation in Planning Power Plant Projects in Thailand, Thammasat International Journal for Science and Technology Vol. 9; No. 1; January-March 2004.

[8] Cogan, Sharpe and Hertberg, 1986, "Citizen Participation", Chapter 12 in The Practice of State and Regional Planning, edited by So, FrankS. II, Hand, Irving, and McDowell, Bruce D., American Planning Association, p. 283-308.

[9] Arnstein, Sherry R., 1969, A Ladder of Citizen Participation, Journal of the American Institute of Planners (JAIP), Vol. 35, No. 4, July 1969, pp. 216-224.

[10] Office of Natural Resources and Environmental Policy and Planning (ONEP) Thailand, 2013, Environmental Quality Management Plan (in Thai). Retrieved on October, 30, 2013, from http://www.onep.go.th/index.php?option=com_content\& view $=$ article\&id $=2761 \&$ Itemid $=173$.

[11] The National Economic and Social Development Board (NESDB), 2011, The Eleventh National Economic and Social Development Plan B. E. 2555 - 2559 (A. D. 2012 - 2016) (in Thai), Office of the National Economic and Social Development Board, Bangkok, Thailand.

[12] Enhancement and Conservation of National Environmental Quality Act B. E. 2535 (in Thai), 1992, Royal Gazette, Thailand. Vol. 109. 